\title{
PERAN PUBLIC RELATION TAK SEKEDAR FUNGSI TEKNIS
}

\author{
Nurul Candrasari Masykuri \\ Jurusan Marketing dan Komunikasi, Fakultas Komunikasi dan Multimedia, Bina Nusantara University \\ Jln. K.H. Syahdan No. 9, Kemanggisan, Palmerah, Jakarta Barat 11480
}

\begin{abstract}
Article explored many functions of Public Relations (PR). It is one department in an organization that is responsible for matters relating to community relations and has responsibility for the company image. $P R$ is also responsible for inter-departmental relationships that exist within the organization. So, not only outward, but inward. $P R$ bridges all the problems that occur between departments. In maintaining and improving the quality of image, $P R$ will create a lot of programs to promote the company to the center of the community. The essence of $P R$ must prepare and obtain more data concerning these trends through surveys, research, and observation in the intensive and continuous. The function of $P R$ is essential in every point of planning and corporate development. PR should know the effects of packaging a product that will be offered to customers which will become regular customers of these products. In fact, a PR should be able to maintain such image what would happen if the packaging is yellow and what effect if replaced by a red color.
\end{abstract}

Keywords: public relations

\begin{abstract}
ABSTRAK
Artikel membahas berbagai peran Public Relation (PR) yang merupakan suatu bidang dalam organisasi yang bertanggung jawab pada masalah yang terkait dengan hubungan masyarakat, dan bertanggung jawab pada citra perusahaan. $P R$ juga bertanggung jawab pada hubungan inter dan antardepartemen. $P R$ menjembatani semua masalah yang terjadi diantara departemen tersebut. Dalam mengelola dan mengembangkan citra perusahaan, $P R$ banyak membuat kegiatan untuk mempromosikan perusahaan di tengah masyarakat. Hal ini bisa dilakukan dengan survei, riset, dan observasi secara intensif dan berkelanjutan. Fungsi $P R$ sangat nyata, baik dalam setiap kegiatan perencanaan dan pengembangan perusahaan. Kemudian, $P R$ harus mengetahui dampak kemasan produk yang akan ditawarkan ke konsumen, terlebih apabila mereka diharapkan menjadi pengguna produk tersebut secara tetap. Disimpulkan, $P R$ harus mampu mempertahankan citra perusahaan, bahkan ketika terjadi perubahan produk.
\end{abstract}

Kata kunci: public relation 


\section{PENDAHULUAN}

Public relations (PR) adalah salah satu departemen di sebuah organisasi yang bertanggung jawab terhadap hal yang berkaitan dengan hubungan kemasyarakatan. PR adalah salah satu departemen yang memiliki tanggug jawab terhadap company image, karena PR memiliki tanggung jawab terhadap citra yang akan ditampilkan, melindungi, serta meningkatkan kualitas citra perusahaan di tengah masyarakat. PR juga bertanggung jawab terhadap hubungan antardepartemen yang ada dalam organisasi. sehingga, tidak peran mereak tidak hanya hanya ke luar, tetapi juga ke dalam. PR menjembatani semua permasalahan yang terjadi antardepartemen.

Dalam menjaga dan meningkatkan kualitas citra, PR akan membuat banyak program untuk mempromosikan perusahaan ke tengah kalangan masyarakat. PR juga yang merancang program CSR (Corporate Social Responsibility). Di dalam departemen PR orang yang bekerja di dalamnya harus tahu tentang industrial psychology dan consumer psychology. Ilmu itulah yang kelak akan dipergunakan orang PR untuk mempelajari gaya hidup masyarakat, apa yang menjadi keinginan industri, dan trend yang ada di lingkungan setempat.

Selanjutnya hakikat PR adalah harus mempersiapkan dan mendapatkan banyak data yang menyangkut trend tersebut melalui survei, penelitian, maupun pengamatan secara intensif dan terusmenerus. Fungsi PR sangatlah penting dalam setiap titik perencanaan dan pengembangan perusahaan. PR harus tahu efek dari kemasan sebuah produk yang akan ditawarkan kepada konsumen yang kelak akan menjadi pelanggan tetap produk tersebut. Dalam kenyataannya seorang PR harus dapat mempertahankan citra perusahaan, misalnya apa yang akan terjadi bila kemasan tersebut berwarna kuning dan apa efeknya bila diganti dengan warna merah.

\section{METODE PENELITIAN}

Artikel disusun berdasarkan studi pustaka, yaitu mencoba menyeleksi beberapa sumber referensi dan knowledge baik yang tercetak maupun elektronik. Informasi yang dipilih dan terpilih menjadi dasar penyusunan artikel ini.

\section{PENDAHULUAN}

Peran Public Relation (PR) tak sekedar fungsi teknis, artinya peran PR memiliki yang dinamakan efek sebagai ilustrasi. Lihatlah bagaimana sebuah iklan yang di promosikan oleh seorang PR terhadap daya beli masyarakat. PR-lah tempat pertama bertanya bila sudah menyangkut hubungan kemasyarakatan dan daya saing perusahaan. PR juga menganalisis gaya pemasaran dan promosi, baik yang dilakukan oleh perusahaan sendiri maupun perusahaan pesaing. PR juga merancang pelatihan untuk meningkatkan motivasi kerja, kinerja kerja, maupun meningkatkan kualitas kerja karyawan. PR mempelajari cara perekrutan karyawan baru. Mereka menganalisis kepribadian para calon karyawan.

Dengan demikian, fungsi PR tak sekedar fungsi teknis tetapi juga harus tahu tentang ilmu psikologi. Mereka harus menggunakan metode yang sudah terbukti keandalannya. PR tidak boleh mengambil keputusan atas dasar perasaan, melainkan harus berdasarkan peraturan yang ada dan dengan konsep yang sudah tertata baik. Teori Public Relations sangat penting dikuasai PR agar dapat menjunjung nama baik perusahaan. 


\section{HASIL DAN PEMBAHASAN}

Hubungan Masyarakat (humas) seringkali disederhanakan sebagai sebuah terjemahan dari istilah Public Relations (PR). Sebagai ilmu pengetahuan, PR masih relatif baru bagi masyarakat Indonesia. PR sendiri merupakan gabungan berbagai ilmu dan termasuk dalam jajaran ilmusosial seperti ilmu politik, ekonomi, sejarah, psikologi, sosiologi, komunikasi, dll.

Dalam kurun waktu 100 tahun terakhir PR mengalami perkembangan yang sangat cepat. Namun, perkembangan PR di setiap negara tidak sama, baik bentuk maupun kualitasnya.Proses perkembangan PR lebih banyak ditentukan oleh situasi masyarakat yang kompleks.

Kasali ( 2005:1) mengatakan bahwa, "PR merupakan pendekatan yang sangat strategis dengan menggunakan konsep-konsep komunikasi .” Di masa mendatang PR diperkiraan akan mengalami pertumbuhan yang luar biasa. Pemerintah AS mempekerjakan 9000 karyawan di bidang komunikasi yang ditempatkan di United States Information Agency.

Selama ini publik termasuk praktisi PR sendiri cenderung menganggap PR sebagai fungsi teknis untuk promosi dan publikasi dari pada menjadi fungsi manajemen yang strategis. Peran dan fungsi PR menjadi sangat vital seiring dengan kebebasan berpendapat dan berkembangnya media sosial dewasa ini,seperti pernyataan berikut. "Ini masalah serius, terutama terkait .dengan peran dan fungsi strategis PR dalam perusahaan, atau sebuah lembaga. " Selama ini publik termasuk praktisi PR sendiri cenderung menganggap PR sebagai fungsi teknis untuk promosi dan publikasi daripada PR menjadi fungsi manajemen yang strategis. Selanjutnya, di antara hal penting lainnya adalah seorang PR tidak cukup hanya cantik dan menarik, tetapi harus profesional dan berperan strategis karena kekeliruan informasi dari seorang PR bisa berbuntut pada kejadian fatal.”

\section{Perkembangan Public Relation di Dunia}

Dalam sejarahnya istilah Public Relations sebagai sebuah teknik menguat dengan adanya aktivitas yang dilakukan oleh pelopor Ivy Ledbetter Lee yang pada 1906 berhasil menanggulangi kelumpuhan industri batu bara di Amerika Serikat dengan sukes. Atas upayanya ini ia diangkat menjadi The Father of Public Relations.

Perkembangan PR sebenarnya bisa dikaitkan dengan keberadaan manusia. Unsur memberi informasi kepada masyarakat, membujuk masyarakat, dan mengintegrasikan masyarakat adalah landasan bagi masyarakat.

Tujuan, teknik, alat dan standar etika berubah-ubah sesuai dengan berlalunya waktu, misalnya pada masa suku primitif mereka menggunakan kekuatan, intimidasi atau persuasi untuk memelihara pengawasan terhadap pengikutnya. Atau menggunakan hal-hal yang bersifat magis, totem (benda keramat), taboo (hal bersifat tabu), dan kekuatan supranatural.

Penemuan tulisan akan membuat metode persuasi berubah. Opini publik mulai berperan. Ketika era Mesir Kuno, ulama merupakan pembentuk opini dan pengguna persuasi. Pada saat Yunani kuno mulai dikembangkan Olympiade untuk bertukar pendapat dan meningkatkan hubungan dengan rakyat. Evaluasi mengenai pendapat atau opini publik merupakan perkembangan terakhir dalam sejarah kemanusiaan.

Dasar-dasar fungsi humas ditemukan dalam revolusi Amerika. Ketika ada gerakan yang direncanakan dan dilaksanakan. Pada dasarnya, masing-masing periode perkembangan memiliki perbedaaan dalam strategi mempengaruhi publik dan menciptakan opini publik demi perkembangan organisasinya. 


\section{Asal Mula Istilah}

Beberapa Pengertian tentang PR :

- Hubungan dengan masyarakat luas baik melalui publisitas khususnya fungsi-fungsi organisasi dan sebagainya terkait dengan usaha menciptakan opini publik dan citra yang menyenangkan untuk dirinya sendiri.

- Fungsi manajemen yang mengevaluasi sikap publik, mengidentifikasi kebijaksanan dan prosedur seorang individu atau organisasi berdasarkan kepentingan publik dan menjalankan suatu program untuk mendapatkan pengertian dan penerimaan publik.

- Filsafat sosial dan manajemen yang dinyatakan dalam kebijaksanaan beserta pelaksaannya yang melalui interpretasi yang peka mengenai peristiwa-peristiwa berdasarkan pada komunikasi dua arah dengan publiknya, berusaha memperoleh saling pengertian dan itikad baik (Moore, 2004: 6).

Public Relations yang diterjemahkan menjadi hubungan masyarakat (humas) mempunyai dua pengertian. Pertama, humas dalam artian sebagai teknik komunikasi atau technique of communication dan kedua, humas sebagai metode komunikasi atau method of communication (Abdurrachman, 1993: 10). Konsep Public Relations sebenarnya berkenaan dengan kegiatan penciptaan pemahaman melalui pengetahuan, dan melalui kegiatan-kegiatan tersebut akan muncul perubahan yang berdampak (Jefkins \& Yadin, 2004: 2).

Public Relations menyangkut suatu bentuk komunikasi yang berlaku untuk semua organisasi (non profit - komersial, publik- privat, pemerintah - swasta). Artinya Public Relations jauh lebih luas ketimbang pemasaran dan periklanan atau propaganda, dan telah lebih awal.

Dewasa ini, Public Relations harus berhadapan dengan fakta yang sebenarnya, terlepas dari apakah fakta itu buruk, baik, atau tanpa pengaruh yang jelas. Karena itu, staf Public Relations dituntut mampu menjadikan orang lain memahami suatu pesan, demi menjaga reputasi atau citra lembaga yang diwakilinya.

Public Relations, sekali pun sering disamakan dengan humas, namun memiliki perbedaan deskripsi pekerjaan. Tugas seorang PR ternyata jauh lebih luas dari sekedar berhadapan dengan klien ataupun media. demikian,

Edward L. Berneys dalam bukunya yang berjudul Public Relations menyebutkan fungsi PR

“ Seorang PR memiliki tiga fungsi yaitu: sebagai pemberi informasi kepada publik, secara persuasif menjadi pengubah sikap dan tingkah laku publik terhadap lembaga/perusahaan demi kepentingan kedua belah pihak, dan sebagai pengintegrasi antara sikap dan perbuatan lembaga dengan sikap publik dan sebaliknya. Intinya seorang PR bertanggung jawab membina dan menjaga hubungan baik dengan publik sehingga tercipta suatu citra positif tentang perusahaan.”

Untuk mencapai semua tujuan tersebut, seorang PR wajib memiliki kemampuan komunikasi yang holistik.

Ada lima unsur dalam proses komunikasi yang harus dikuasai:, yaitu source /communicator (orang yang menjadi sumber, bisa pejabat yang berwenang/dirinya sendiri); message (pesan yang akan disampaikan); channel (media/sarana penyampaian pesan), target audience (kelompok penerima pesan); dan effect (dampak yang terjadi pada diri komunikan setelah menerima pesan).

Saat ini masih ditemui peran PR yang bersifat methods of communication dan belum state of being (melembaga). Artinya peran PR sesungguhnya saat ini masih dilakukan belum secara 
keseluruhan, namun baru sebatas metode, cara atau aktivitas yang kadang bercampur dengan peranperan dalam organisasi yang lain pemasaran, hukum, dan lain-lain.

Jadi, peran PR belum melembaga secara spesifik atau terpisah dengan tanggung jawab khusus mengenai kehumasan, di antaranya yang sering dijumpai adalah PR masih sebatas seperti dibawah ini:

- Profesi PR menjadi multi entry dicipliner proffesion pada saat ini tampaknya setiap orang dengan background apapun dapat berprofesi PR tanpa syarat dan kompetensi khusus baik khususnya secara akademis.

- Decision Maker pada sebuah perusahaan atau lembaga masih sering belum melibatkan fungsi PR yang sesuai dengan bidang kehumasan, akibatnya peran PR menjadi tidak optimal.

- Peran PR sering masih memiliki berbagia hambatan oleh komitmen manajemen organisasi. Pemahaman top level management yang terbatas terhadap peran PR, yang berakibat peran PR juga tidak dapat berperan secara optimal, sehingga seringkali PR hanya sebatas sebagai buffer atau penyangga, pendukung dalam suatu rangkaian fungsi manajemen semata.

- PR yang seharusnya menjadi ujung tombak sebuah perusahaan atau di sebuah lembaga pada kenyatannya jauh dari top level management. Hal tersebut akan menyebabkan PR akhirnya tak berperan dan tak memiliki kewenangan yang sesuai dengan kebutuhannya. Pada level ini menyebabkan PR tidak dapat memainkan peran strategisnya. Sehingga berdampak pada peran PR hanya sebatas pelaksana atau teknis komunikasi saja.

Beban yang disandang seorang PR ketika melakukan kesalahan akan menyebabkan petaka bagi image perusahaan. Pernyataan yang dikeluarkan PR dianggap mewakili sikap perusahaan terhadap suatu kondisi/hal. Oleh sebab itu, seorang PR harus selalu berhati-hati dan harus tepat dengan mengedepankan berbagai aspek, di antaranya aspek mutual understanding antara kedua belah pihak dengan konsumen mereka.

Sebagai contoh kasus:

Ketika sebuah produk yang diunggulkan dari perusahaan kecantikan, misalnya menawarkan produk yang akan dapat membuat kulit menjadi lebih putih, bercahaya, dan menahan efek penuan , namun kenyataannya ternyata ada beberapa konsumen merasa bahwa yang ditawarkan tak menjadi kenyataan, maka bagaimanakah seorang PR harus menjelaskan semua hal tersebut? Hal ini bukanlah hal yang mudah, terlepas dari apa pun harus ada pendekatan yang persuasive, psikologis menenangkan, dan harus memberikan jawaban pas yang rasional juga harus berdasarakan fakta dan masuk akal. Bagaimana pun juga konsumen akan banyak berharap akan tanggung jawab dari penawaran dan pencitraan produk tersebut. Di sinilah letak kunci keberhasilan seorang PR, apakah dapat mengatasi masalah tersebut dengan damai dan membuat kepuasan pada konsumen atas jawaban yang diberikan. Semua ini tidak terlepas dari pengetahuan, berbagai pengalaman, dan kematangan seorang PR untuk tetap tenang memberikan jawaban yang bijaksana. Tentu saja keadaan ini memerlukan penguasaan komunikasi persuasive, pengetahuan yang cukup, dan pengetahuan psikologis untuk mengatasi situasi tersebut. Dari kasus ini terlihat nyata bahwa sebuah pendekatan tidak hanya bersifat teknis semata yang harus dimiliki seorang PR, namun banyak sisi yang akan membuat sebuah brand atau produk sebuah perusahaaan mampu berjaya.

Selanjutnya, sebelum menghakimi dan melabeli seorang PR dengan sebutan baik atau buruk maka perlu diketahui persyaratan seorang PR yang baik. Resume yang dibuat Daniel Buana mengatakan bahwa seorang PR yang baik harus memiliki kemampuan berkomunikasi, kepemimpinan, bergaul dan membina relasi, kepribadian yang jujur dan kredibel, serta kreatif.

Kemampuan berkomunikasi tidak terbatas pada komunikasi verbal namun juga tulisan bahkan visual. Seorang PR harus fasih berkomunikasi dalam berbagai jenis media, misalnya saat presentasi, wawancara, dialog, membuat berita/artikel/press release, dsb. Tujuannya untuk menjalankan fungsinya sebagai penyampai informasi atau komunikator. Ia harus tahu bagaimana memperlakukan 
media sesuai dengan karakteristik, target audience, dan efek yang akan hasilkan pada komunikan (penerima pesan).

Kemampuan manajerial/kepemimpinan juga penting untuk menerjemahkan visi dan misi dari manajemen tertinggi. Ia harus tahu seluk beluk perusahaan, mengerti tingkah laku dan memperhatikan konsumen, karyawan dan kelompok lain yang berkepentingan dengan tugasnya sebagai penghubung. Seringkali PR dihadapkan pada situasi krisis yang membutuhkan respon cepat dan tepat. Diperlukan kematangan berpikir dan kecepatan bertindak untuk bisa meng-handle keadaan secara tenang dan elegan. Jiwa leadership juga diperlukan untuk melakukan koordinasi antar pihak-pihak yang terkait.

Kemampuan bergaul dan membina relasi. Fleksibilitas dalam menghadapi berbagai jenis kepribadian dan kemampuan berinteraksi dengan orang dari berbagai tingkatan, termasuk juga memanfaatkan networking untuk mendapatkan informasi yang dibutuhkan layaknya seorang detektif. Kepandaian bergaul juga penting untuk membangun opini positif terhadap perusahaan sehingga tercipta hubungan saling percaya. Diperlukan orang dengan tipe kepribadian extrovert untuk bisa menjalankan tugas ini.

Kepribadian yang jujur dan kredibel harus dimiliki oleh seorang PR. Seorang PR haruslah orang yang bisa dipercaya, artinya yang dikatakan harus dilandasi oleh fakta dan bukan sekedar pemanis demi menaikkan popularitas perusahaan. Informasi yang diberikan harus akurat dan cukup penting untuk diketahui masyarakat. Selain itu, dalam menjalankan tugasnya ia harus mematuhi etika dan menjunjung tinggi moralitas. Sekalipun tugasnya adalah menjaga image perusahaan agar tetap positif di mata publik, namun tidak lantas membuat PR merasa berhak menjatuhkan pihak lain yang berseberangan dengannya. Selayaknya PR membuat pernyataan yang netral, objektif, simpatik, dan memperhatikan nilai kemanusiaan.

Seorang PR harus kreatif dan kaya ide, artinya seorang PR memiliki wawasan luas dengan kemampuan berpikir kreatif serta kritis sangat diperlukan, terutama untuk menghadapi berbagai masalah yang membutuhkan alternatif penyelesaian. Seorang PR juga harus pandai membaca peluang dan melihat celah tempat ia bisa meningkatkan keunggulan perusahaan di depan publik. Kemampuan menciptakan strategi baru untuk memperluas hubungan antara perusahaan dengan publik pun menjadi sebuah kriteria yang penting untuk dimiliki oleh seorang PR

\section{PENUTUP}

\section{Peran penting PR dalam Pemasaran}

Berlawanan dengan yang banyak orang percaya, PR dan pemasaran adalah dua hal yang sangat berbeda.. Namun, kedua hal tersebut memberikan kontribusi bagi keberhasilan perusahaan.

Bagaimana PR dan pemasaran yang berbeda? "Marketing deals primarily with product awareness and promotion“. Pemasaran berkaitan terutama dengan kesadaran produk dan promosi. Mereka yang terlibat dengan pekerjaan pemasaran untuk mempromosikan produk tertentu atau jasa perusahaan atau penawaran organisasi. Profesional Marketing akan menyibukkan diri dengan produk perusahaan menyediakan, pelanggan dan kebutuhan mereka, dan kemudian bekerja untuk mengantisipasi apa produk berikutnya akan atau bagaimana mempromosikan.

Selanjutnya, PR dikatakan sebagai:

PR or public relations, handles the image of the company itself, whereas marketing is concerned primarily with products. A public relations professional is more concerned with the public's 
view of the company and the company's reputation rather than trying to get the public to purchase the products

Dengan demikian dapat dikatakan bahawa PR atau hubungan masyarakat berfungsi untuk menangani citra sebuah perusahaan, sementara pemasaran terutama berkaitan dengan produk. Sebenarnya seorang profesional PR akan lebih peduli terhadap pandangan dan pencitraan publik perusahaan serta reputasi perusahaan dibanding hanya sekedar mencoba mengajak masyarakat untuk membeli produk, walaupun sudah barang tentu ketika sebuah produk telah berhasil memiliki posisi tawar yang sudah mencapai terkenal maka akan dengan sendirinya pelanggan atau konsumen akan menghampiri.

Seorang PR yang sukses kampanye dalam departemen akan bekerja untuk melakukan hal berikut: meningkatkan dan mempertahankan kesadaran visibilitas dan publik perusahaan, organisasi, atau acara ; membantu masyarakat untuk melihat organisasi sebagai pemimpin industri ; meningkatkan kesadaran program organisasi, produk, dan jasa di seluruh negari dan kesadaran masyarakat, atau dunia; membantu meningkatkan dan mempertahankan citra organisasi; bertindak sebagai juru bicara dan mediator dalam kasus organisasi atau pejabat yang menerima publikasi negatif; meningkatkan semangat kerja karyawan dan membantu untuk merekrut dan mempertahankan karyawan .

Seberapa pentingkah PR dalam pemasaran?, PR dan pemasaran adalah saling bergandengan tangan, Seorang konsumen akan segera membeli produk atau menggunakan layanann tergantung dari cara seorang PR memiiki strategi pendekatan dalam pelayanan terhadap konsumen. Keberhasilan seorang PR dalam pemasaran semua hal tersebut tak terlepas dari peran tim PR untuk menanamkan kepercayaan kepada public atau kepada konsumen sebagai target market. Seorang PR yang baik sudah selayaknya dan seharusnya memahami apa yang menjadi kebuttuhan dan apayang menjadi keinginan serta hasrat dari para pelanggannya kelak.

Tugas PR lebih mudah ketika ia berada pada posisi perusahaan yang sedang naik tinggi dan dengan produk yang dihormati, dan jauh lebih sulit ketika perusahaan turun dan produknya tidak dihormati, seperti pernyataan berikut.

"Since perception lags reality by many years, the former situation can lead to arrogance, believing you'll get good treatment and reviews regardless what you do.. The latter can be challenging and frustrating, believing that no matter how hard and well you work, no matter how good your products may be, they're rarely given an open mind and a fair shake"

\section{DAFTAR PUSTAKA}

Abdurrachman, O.(1993). Dasar-dasar Public Relations. Bandung: Citra Aditya Bakti

Effendy, O.U.( 1999). Hubungan Masyarakat. Suatu Study Komunikologis. Cetakan ke lima. Bandung: Remaja Rosdakarya.

Jefkins, F., \& Yadin, D. (1996). Public Relations. Edisi Kelima. Jakarta: Erlangga.

Kasali, R. (2005). Manajemen Public Relations. Jakarta: Grafiti.

Moore, F. (2004). Humas, Membangun Citra dengan Komunikasi. Bandung: Rosda. 